\title{
Fluoride in Polish Drinking Water and the Possible Risk of Dental Fluorosis
}

\author{
Maria Borysewicz-Lewicka, Justyna Opydo-Szymaczek* \\ Department of Pediatric Dentistry, Poznan University of Medical Sciences, \\ Bukowska 70, 60-812 Poznan, Poland
}

Received: 2 October 2015

Accepted: 23 October 2015

\begin{abstract}
The role of fluoride in dental caries prevention is well-documented. However, excessive fluoride exposure may have detrimental effects on human health. The first overt sign of chronic fluoride overdose is enamel fluorosis. The increasing prevalence of this condition has been observed recently due to widespread use of water fluoridation, dental cavity prevention products, and environmental pollution. Our review provides basic information regarding the sources of fluoride exposure in Poland, with special attention to drinking water as well as current Polish and European Union legislation on drinking water quality. The notion of infant formula reconstituted in fluoridated water as a risk factor for enamel fluorosis development is discussed. The implications of setting the upper limit of fluoride content in the drinking water at $1.5 \mathrm{mg} / \mathrm{l}$ were mentioned. The need for increasing knowledge about adverse effects of fluoride as well as the availability of data on fluoride content in the environment is emphasized.
\end{abstract}

Keywords: fluoride, drinking water, Poland, dental fluorosis

\section{Health Effects of Fluoride}

The use of fluoride has been a major factor in the global decline of dental caries [1]. The World Health Organization (WHO) and the World Dental Federation (FDI) have called for the promotion of fluoride dental caries prevention, highlighting its efficacy and safety [2-5].

However, excessive exposure to fluoride can cause a number of adverse effects. These may range from mild dental fluorosis to crippling skeletal fluorosis, depending on the level and period of exposure. Moreover, results of some animal and epidemiological studies suggest that fluoride demonstrates nephrotoxicity, neurotoxicity, carcinogenicity, genotoxicity, and may adversely affect thyroid function and fertility [5-7].

\footnotetext{
*e-mail: jopydo@ump.edu.pl
}

Dental fluorosis is the first overt side effect of chronic fluoride toxicity, and its occurrence is associated with cumulative fluoride exposure during enamel development. In its most mild form fluorosis appears as barely discernible white lines running across the teeth, and in advanced stages as brown and black stains plus pitting and cracking of the enamel. Enamel fluorosis may develop during the first eight years of life. Later enamel is no longer sensitive to excessive fluoride, since its preeruptive maturation is complete [1, 7]. The critical period for development of fluorosis in permanent maxillary central incisors are the first two years of life. Thus, excessive fluoride intake during early childhood negatively affects the most aesthetically important teeth [8].

Recent decades have seen an increasing number of cases of enamel fluorosis that have been observed both in areas with fluoridated water and areas with low fluoride content in the drinking water [9-13]. Literature data indicate that, currently, enamel fluorosis may affect from 
$5 \%$ to $43 \%$ of residents of non-fluoridated communities [9-11], while at the beginning of fluoride research this rate did not exceed $2 \%[14,15]$. This indicates that fluoride exposure from various sources has significantly increased.

In Polish national epidemiological surveys children are not screened for developmental defects of enamel, so little is known about their prevalence. The study of WochnaSobańska et al. [16] on four populations of 12-year-olds revealed that in localities with levels of fluoride in the drinking water of $1.25 \mathrm{mg} / 1,1.35 \mathrm{mg} / 1,1.60 \mathrm{mg} / \mathrm{l}$, and $0.25 \mathrm{mg} / \mathrm{l}$, the prevalence of fluorosis was $18.2 \%, 33.4 \%$, $35.7 \%$, and $0 \%$, respectively. Czajka-Jakubowska reported that in the city of Środa Wielkopolska, where the level of fluoride in the drinking water ranged from 0.8 to $1.2 \mathrm{mg} / \mathrm{l}$, $31 \%$ of 18 -year-olds was affected by dental fluorosis [17].

Our own recent studies of the population of 6-14-yearold schoolchildren living in Śrem Commune(Wielkopolska Province), where the level of fluoride in the drinking water does not exceed $0.4 \mathrm{mg} / \mathrm{l}$, revealed that $17 \%$ of the subjects had their dentition affected by fluorosis and $11 \%$ of the subjects had fluoride enamel opacities affecting teeth that develop during early childhood (i.e. the first permanent molars and incisors) [11, 18].

\section{Safety Considerations}

The issue of safety of fluoride dental caries prevention has become a subject of interest of WHO experts, expressed in a series of reports and elaborations concerning this topic edited by WHO $[2,4,5]$. Experts have emphasized that an assessment of total fluoride exposure from various sources plays a key role in assuring the safe use of fluorides.

It is noteworthy that, according to current knowledge, the predominant caries preventive effect of fluoride is posteruptive and topical, which means that fluoride works mainly after teeth have erupted, when small amounts are present in dental plaque and saliva. Ingestion of fluoride is not essential for dental caries prevention. Thus, the modern concept of fluoride caries prevention involves maximizing the local effects and limiting swallowing of excessive fluoride during dentition development $[1,7]$.

In Poland the safety of fluoride prophylaxis has also become the matter of numerous debates. Unfortunately, the level of knowledge of medical staff supervising or recommending fluoride prophylaxis is unsatisfactory [19]. Similarly, a study conducted in Malbork, a city with elevated fluoride content (up to $3.2 \mathrm{mg} / \mathrm{l}$ ), revealed insufficient knowledge of the teenage respondents about the risks associated with consumption of excessive doses of fluoride [20].

"Current knowledge of individual fluoride prevention of dental caries of children and young adults" was published in 2013 [21]. This paper, prepared on the initiative of the Polish Dental Society, contains the newest guidelines on the use of fluoride in dental caries prevention in Poland. As emphasized by the authors, "Due to its high cytostatic activity and little difference between therapeutic and toxic doses, fluoride requires a very careful application." New recommendations, patterned on European Academy of Paediatric Dentistry guideline [22], limit the use of fluoride supplements to cases of confirmed high-risk dental caries development in regions with low fluoride content in the drinking water $(<0.3 \mathrm{mg} / \mathrm{l})$. Supplements are not recommended for children under the age of three years, since they increase the risk of fluorosis of the permanent front teeth. Fluoridated toothpaste is recommended starting from the eruption of the first primary teeth, provided that parents supervise the procedure and comply with a proper dosing schedule. The guideline is an expression of the modern trend in dental caries prophylaxis, assuming individual attitudes to every patient's therapy after considering the risk of dental caries and dental fluorosis.

\section{Sources of Fluoride Exposure}

Fluorine occurs in the environment in air, water, and soil, and in living organisms. Natural sources of fluorides are volcanic eruptions and geysers, the dissolution of minerals, and marine aerosols. The main anthropogenic sources include aluminum smelters; phosphate fertilizer factories; glass, brick, and ceramic manufacturing; and glue and adhesive production $[1,4,6]$. Data concerning fluoride concentrations in the atmosphere of Europe are limited, since air-monitoring institutions do not routinely investigate this parameter. A 2010-11 study of fluoride levels in the air of Wielkopolski National Park revealed considerable concentrations (maximum $9.7 \mu \mathrm{g} / \mathrm{m}^{3}$ ), close to the daily allowable level $\left(10 \mu \mathrm{g} / \mathrm{m}^{3}\right)$. It was attributed among others to the neighborhood of local emitters, such as Luvena chemical plant and the agglomeration of Poznan [23]. Although fluoride might be a component of air pollution, inhalation exposure to this compound is not considered important for the general population in the European Union. It does not contribute more than $0.01 \mathrm{mg} /$ day to total intake, except in occupational settings (e.g., aluminum workers where intake can be several milligrams) [6].

Among various dietary compounds, infant formulas prepared with the use of fluoridated water, grape juice, tea and beverages containing tea extract, bottled waters, fish, and chicken have been recognized as important sources of fluoride intake [24-29]. The use of fluoride dentifrice during early childhood and improperly prescribed fluoride supplements are also thought to be significant risk factors for enamel fluorosis. It has been estimated that approximately $0.5 \mathrm{mg}$ of fluoride may be ingested by children when a $0.1 \%$ fluoride toothpaste is used twice daily. Fluoride supplements usually contain 0.25 to $1 \mathrm{mg}$ of fluoride per tablet [30, 31].

Despite the variety of fluoride sources in the environment, fluoride content in tap water remains a basic indicator of fluoride exposure of the population.

In Poland water is not artificially fluoridated. A 1996 study by Czarnowski et al. [32] on fluoride content in 94 localities in northern and central Poland revealed that in the 
Table 1. Fluoride concentrations in drinking water in capital cities of Polish provinces (data presented on websites of water suppliers in August 2015).

\begin{tabular}{|c|c|c|c|}
\hline City & $\begin{array}{l}\text { Fluoride content } \\
{[\mathrm{mg} / \mathrm{l}]}\end{array}$ & Sampling period & Source \\
\hline Wrocław & $0.13-0.19$ & $2^{\text {nd }}$ quarter 2015 & http://www.mpwik.wroc.pl \\
\hline Bydgoszcz & $0.093-0.34$ & $2^{\text {nd }}$ quarter 2015 & http://bip.mwik.bydgoszcz.pl \\
\hline Toruń & Fluoride content not disclosed & $2^{\text {nd }}$ quarter 2015 & http://www.wodociagi.torun.com.pl \\
\hline Lublin & $<0.5$ & $2^{\text {nd }}$ quarter 2015 & http://www.mpwik.lublin.pl \\
\hline Gorzów Wielkpolski & Fluoride content not disclosed & $2^{\text {nd }}$ and $3^{\text {rd }}$ quarter 2015 & http://www.pwikgo.pl \\
\hline Zielona Góra & $0.08-0.16$ & $2^{\text {nd }}$ quarter 2015 & http://www.zwik.zgora.pl \\
\hline Łódź & $0.10-0.18$ & July 2015 & http://www.zwik.lodz.pl \\
\hline Kraków & Fluoride content not disclosed & $2^{\text {nd }}$ quarter 2015 & http://www.mpwik.krakow.pl \\
\hline Warszawa & $0.067-0.15$ & July 2015 & http://www.mpwik.com.pl \\
\hline Opole & Fluoride content not disclosed & July 2015 & http://wikopole.com.pl \\
\hline Rzeszów & Fluoride content not disclosed & $2^{\text {nd }}$ quarter 2015 & http://www.mpwik.rzeszow.pl \\
\hline Białystok & Fluoride content not disclosed & July 2015 & http://www.wobi.pl \\
\hline Gdańsk & $0.1-1.6$ & July 2015 & http://www.sng.com.pl \\
\hline Katowice & Fluoride content not disclosed & $2^{\text {nd }}$ quarter 2015 & http://wodociagi.katowice.pl \\
\hline Kielce & $<0.1$ & sampling period not stated & http://wod-kiel.com.pl \\
\hline Olsztyn & Fluoride content not disclosed & August 2015 & http://www.pwik.olsztyn.pl \\
\hline Poznań & $0.14-0.56$ & $2^{\text {nd }}$ quarter 2015 & http://www.aquanet.pl \\
\hline Szczecin & Fluoride content not disclosed & $1^{\text {st }}$ quarter 2015 & http://zwik.szczecin.pl \\
\hline
\end{tabular}

majority of the studied country areas (62 localities) fluoride concentration was below $0.3 \mathrm{mg} / \mathrm{l}$; however, in 24 localities it ranged from 0.3 to $1.0 \mathrm{mg} / \mathrm{l}$ and in eight localities it even exceeded $1.0 \mathrm{mg} / \mathrm{l}($ with a peak value $=3.0 \mathrm{mg} / \mathrm{l})$.

\section{Polish and European Union Legislation on the Quality of Drinking Water}

According to the EU Drinking Water Directive [33], the memberships of the European Union are obliged to introduce constant monitoring of water quality used for human consumption. Requirements concerning the quality of such water, including bacteriological, physical, chemical, and organoleptic requirements, are laid down in the Regulation of the Minister of Health of 29 March 2007 on the quality of water intended for human consumption with further amendments $[34,35]$. According to the regulation, the set of parameters that needs to be taken into account while monitoring drinking water includes fluoride concentration. The quality of water is supervised by the state sanitary inspector. Water supply companies and water supply network laboratories provide the state district sanitary inspector with access to data necessary to evaluate the quality of water intended for human consumption. When permissible values are exceeded for parameters defined in the regulation of the minister of health and the supply of drinking water cannot be maintained by any other reasonable means, the water supply must apply to the competent state district or border sanitary inspector for derogation. Derogation is possible only after considering health risk and obtaining a specific authorization and must be limited to the shortest time possible. One may apply for derogation no more than three times, each time for a period not exceeding three years. During the derogation period, durable solutions are supposed to be found. It is also required to implement a plan of remedial actions and inform the sanitary inspection on the progress achieved. First and second derogations are the responsibility of the national sanitary inspector. In the case of a third derogation, it is the European Commission who decides whether or not to grant permission [33-35].

According to a Chief Sanitary Inspectorate report, in 2014 about $98 \%$ of the Polish population had access to water suitable for consumption (meeting requirements set out in the regulation) and $2 \%$ to water suitable for consumption under conditions of derogation or water conditionally suitable for consumption. About 36 million people in Poland have access to public water supply, but more than 2 million use private water wells, which do not have to comply with drinking water regulations [36].

From 2010 to 2014, State Sanitary Inspection granted 14 derogations for fluoride content in the drinking water (eight first derogations and six second derogations). They 
Table 2. Fluoride intake from $1.5 \mathrm{ppm}$ fluoride water used to prepare milk formula, and upper tolerable intake levels (UL) of fluoride for infants aged 1-6 and 7-12 months.

\begin{tabular}{|c|c|c|c|}
\hline $\begin{array}{c}\text { Age } \\
{[\text { months }]}\end{array}$ & $\begin{array}{c}\mathrm{UL}^{\mathrm{a}} \\
{[\mathrm{mg} / \mathrm{day}]}\end{array}$ & $\begin{array}{c}\text { Amount of water used to prepare formula } \\
{[\mathrm{ml}]}\end{array}$ & $\begin{array}{c}\text { Fluoride intake }^{\mathrm{b}} \\
{[\mathrm{mg}]}\end{array}$ \\
\hline $1-6$ & 0.7 & $567-810$ & $0.8505-1.215$ \\
\hline $7-12$ & 0.9 & $540-621$ & $0.810-0.9315$ \\
\hline
\end{tabular}

${ }^{a}$ Based on a UL of $0.10 \mathrm{mg} / \mathrm{kg} /$ day of fluoride and an average body weights of $7 \mathrm{~kg}$ and $9 \mathrm{~kg}$ for infants aged 1-6 months and $7-12$ months, respectively [51]

${ }^{\mathrm{b}}$ Assuming that infants aged 1-6 months drink 630-900 ml of milk formula daily, infants aged 7-12 months drink 600-690 ml of formula daily, and $90 \mathrm{ml}$ of water is used for preparation of $100 \mathrm{ml}$ of formula [53]

concerned mainly small water supplies (not exceeding $1,000 \mathrm{~m}^{3}$ a day as an average or serving no more than 5,000 persons) [36-40].

During recent years elevated fluoride levels (up to $4.0 \mathrm{mg} / \mathrm{l}$ ) were observed in Pomerania Province (Cedry Wielkie Commune, Gniew Commune, Tczew Commune, the city of Gdansk, and the city of Malbork), Opole Province (the village of Kopice in Nysa County and the village of Kałków in Brzeg County), and public cretaceous wells in Toruń [41-47].

Most large water suppliers in Poland disclose information on various aspects of water quality on their websites. Table 1 presents website information on fluoride content in the drinking water provided by water suppliers from the capital cities of Polish provinces. Only in the city of Gdańsk did concentration of fluoride in the tap water in 2015 exceed the upper limit of $1.5 \mathrm{mg} / \mathrm{l}$. Nine water suppliers did not include fluoride on the list of examined parameters.

It must be remembered that, according to both Polish and European regulations, the content of fluoride in the drinking water should not exceed the limit of $1.5 \mathrm{mg} / 1$ [33$35]$. From the point of view of dental caries prevention this limit seems relatively high. Already in 1994 WHO reduced its so-called recommended fluoride content in drinking water to the range $0.5-1.0 \mathrm{mg} / 1$ [5]. In 2015 the U.S. Department of Health and Human Services released the new Public Health Service (PHS) recommendation for the optimal fluoride level in drinking water to prevent tooth decay. The new recommendation is for a single level of $0.7 \mathrm{mg} / \mathrm{l}$. It updates and replaces the previous recommended range $(0.7-1.2 \mathrm{mg} / \mathrm{l})$ issued in 1962 . The lower level is to maintain the protective decay prevention benefits of water fluoridation and reduce the occurrence of dental fluorosis [48].

As reminded by WHO experts, national standards for fluoride should be set after considering the intake of water by the population of interest and the intake of fluoride from other sources (e.g., from food, air, and dental preparations). Where the intakes from other sources are likely to approach, or be greater than, $6 \mathrm{mg} /$ day, it would be appropriate to consider setting standards at concentrations lower than the guideline value of $1.5 \mathrm{mg} / 1$ [49]. However, a considerable body of evidence indicates that intakes much lower than $6 \mathrm{mg} /$ day can contribute to the development of dental fluorosis in infants [50].

\section{Artificial Feeding as a Risk Factor of Fluoride Overdosing}

In 1997 the U.S. Institute of Medicine released upper limit (UL) recommendations for daily intake of fluoride. These limits were based on an average, chronic daily fluoride intake of $0.10 \mathrm{mg} / \mathrm{kg}$ b.w., which seems to be the threshold beyond which moderate enamel fluorosis appears in some children [51]. However, Fomon et al. [50], who analyzed risk factors for dental fluorosis in children, suggest striving for intakes less than $0.07 \mathrm{mg} \mathrm{F} / \mathrm{kg}$ b.w.

Since breast milk contains low concentrations of fluoride (mean $0.01 \mathrm{mg} / \mathrm{l}$ ), breastfed infants receive only about $0.01 \mathrm{mg}$ of fluoride daily [51]. According to current European legislation, infant formula must also contain low fluoride levels [52]. However, when powdered concentrate is mixed with fluoridated water, a baby may receive high fluoride doses per kilogram of body weight. In children who use formula as a primary source of nutrition, fluoride intake exceeds the recommended upper limits $[29,51]$. Table 2 presents a hypothetical calculation of fluoride intake from fluoridated drinking water (1.5 mg/l of fluoride) used for reconstituting milk formula in artificially-fed infants, based on the current Polish infant feeding guidelines [53].

Our own studies on fluoride content in Polish breast milk substitutes confirmed that infant formula itself contains low levels of fluoride, but when reconstituted in water containing more than $0.5 \mathrm{mg} / \mathrm{l}$ of fluoride it may increase the daily fluoride intake of children over UL (0.1 mg/kg b.w.) [29]. Moreover, calculation revealed that in order to keep fluoride intake from formula below the upper limit of $0.07 \mathrm{mg} / \mathrm{kg}$ b.w., the youngest infants should be fed with formula reconstituted in water containing no more than $0.3 \mathrm{mg} / \mathrm{l}$ of fluoride $[27,51]$.

In the United States, the American Dental Association issued interim guidance on fluoride intake for infants and young children, suggesting that in areas with fluoridated water, if liquid concentrate or powdered infant formula is the primary source of nutrition it should be mixed with water that is fluoride-free or contains low levels of fluoride to reduce the risk of fluorosis [54]. Already in 1989 Ekstrand recommended that bottled or deionized water with low concentration of fluoride should be used instead of fluoridated water to dilute the formula [55]. 
However, fluoride content of bottled waters may also differ significantly. While tap water for human consumption must not contain more than $1.5 \mathrm{mg} / 1$ of fluoride, bottled waters might have higher concentrations. Some authors detected extremely high fluoride levels in commercially available bottled waters exceeding $5.0 \mathrm{mg} / \mathrm{l}$. Moreover, many bottled waters did not show fluoride content on their labels [56]. Regulations of the Polish minister of health concerning natural mineral waters, spring waters, and table waters do not obligate manufacturers to display precise values of fluoride content in the product [57]. According to Polish and European legislation, the label should clearly state the following information:

- "Contains more than $1.5 \mathrm{mg} / \mathrm{l}$ of fluoride; not suitable for regular consumption by infants and children under 7 years of age" when fluoride content in the product exceeds $1.5 \mathrm{mg} / \mathrm{l}$.

- "Contains fluoride" when the product contains more than $1.0 \mathrm{mg} / \mathrm{l}$ of fluoride.

The content of fluoride in bottled waters available in Poland range from 0.01 to $1.39 \mathrm{mg} / 1$ [26, 58]. However, our own studies have revealed that all Polish brands of bottled waters labeled as being intended for infants and young children contain low fluoride content $(\leq 0.3 \mathrm{mg} / \mathrm{l})$ and thus can be used for preparation of milk formula instead of tap water [59].

\section{Conclusions}

The review of available reports revealed that fluoride content of drinking water in the majority of the water intakes does not exceed the upper limits established by Polish and international legislation, apart from rare deviations concerning mainly small water suppliers.

However, the upper limit is relatively high and does not assure elimination of risk for dental fluorosis development. Infants fed with formula reconstituted in water are particularly susceptible to fluoride overdosing. Parents who use infant formula should obtain precise advice from health professionals about how to avoid excessive fluoride intake in their children. Since recommendations on the use of fluoride prophylaxis should consider total fluoride exposure, the availability of information about current fluoride levels in tap water should be improved. It would be advisable to present these data on the websites of water suppliers. Knowledge about the adverse health effects of fluoride is still lacking, so there is a need to increase education in this area.

\section{References}

1. CENTERS FOR DISEASE CONTROL AND PREVENTION. Recommendations for using fluoride to prevent and control dental caries in the United States. MMWR 50 (14), 1, 2001.

2. PETERSEN P.E., LENNON M.A. Effective use of fluorides for the prevention of dental caries in the 21 st century: the
WHO approach. Community Dent. Oral Epidem. 32 (5), 319, 2004.

3. FDI WORLD DENTAL FEDERATION. FDI policy statement on promoting oral health through water fluoridation. Int. Dent. J. 64 (6), 287, 2014.

4. FAWELL J., BAILEY K., CHILTON J., DAHI E., FEWTRELL L., MAGARA Y. Fluoride in Drinking-water. WHO, Geneva, 2006.

5. WHO: Fluorides and Oral Health: Rapport of a WHO Expert Committee on Oral Health Status and Fluoride Use. WHO Technical Report Series No. 846. Geneva, 1994.

6. SCHER. Opinion on critical review of any new evidence on the hazard profile, health effects, and human exposure to fluoride and the fluoridating agents of drinking water - 16 May 2011. Accessed 29 September 2015, Available at: http:// ec.europa.eu/health/scientific_committees/environmental_ risks/docs/scher_o_139.pdf

7. ISMAIL A.I., HASSON H. Fluoride supplements, dental caries and fluorosis: a systematic review. J. Am. Dent. Assoc. 139 (11), 1457, 2008.

8. HONG L., LEVY S.M., BROFFITT B., WARREN J.J., KANELLIS M.J., WEFEL J.S., DAWSON D.V. Timing of fluoride intake in relation to development of fluorosis on maxillary central incisors. Community Dent. Oral Epidemiol. 34 (4), 299, 2006.

9. ANGELILLO L.F, TORRE I., NOBILE C.G.A., VILLARI P. Caries and Fluorosis Prevalence in Communities with Different Concentrations of Fluoride in the Water. Caries Res. 33 (2), 114, 1999.

10. ECKERSTEN C., PYLVÄNEN L., SCHRÖDER U., TWETMAN S., WENNHALL I., MATSSON L. Prevalence of dental fluorosis in children taking part in an oral health programme including fluoride tablet supplements from the age of 2 years. Int. J. Paediatr. Dent. 20 (5), 347, 2010.

11. OPYDO-SZYMACZEK J., GERRETH K. Enamel fluorosis and its association with dental caries in a nonfluoridated community of Wielkopolska, Western Poland. Fluoride 46 (4), 234, 2013.

12. LEVY S.M. An update on fluorides and fluorosis. J. Can. Dent. Assoc. 69 (5), 286, 2003.

13. PENDRYS D.G. Risk of enamel fluorosis in nonfluoridated and optimally fluoridated populations: considerations for the dental professional. J. Am. Dent. Assoc. 131 (6), 746, 2000.

14. DEAN H.T., JAY P., ARNOLD F.A. JR, ELVOVE E. Domestic water and dental caries. II. A study of 2,832 white children, aged 12-14 years, of 8 suburban Chicago communities, including Lactobacillus acidophilus studies of 1,761 children. Public Health Rep. 56 (15), 761, 1941.

15. DEAN H.T., ARNOLD F.A. JR, ELVOVE E. Domestic water and dental caries. V. Additional studies of the relation of fluoride domestic water to dental caries experience in 4,425 white children, aged 12 to 14 years, of 13 cities in 4 states. Public Health Rep. 57 (32), 1155, 1942.

16. WOCHNA-SOBAŃSKA M., SZYDŁOWSKAWALENDOWSKA B., LUBOWIEDZKA-GONTAREK B., PROC P. Prevalence of dental fluorosis and caries in 12-yearold children living in areas with high levels of fluoride in drinking water. Czas. Stomatol. 62 (3), 178, 2009 [In Polish].

17. CZAJKA-JAKUBOWSKA A. Effect of the interaction of amelogenin and enamel crystals in clinical and experimental fluorosis, Wydaw. Nauk. Uniw. Med. im. K. Marcinkowskiego, Poznań 2009 [In Polish].

18. OPYDO-SZYMACZEK J., GERRETH K. Developmental enamel defects of the permanent first molars and incisors and their association with dental caries in the region of 
Wielkopolska, Western Poland. Oral Health Prev. Dent. doi: 10.3290/j.ohpd.a33088, 27 Nov 2014. [Epub ahead of print]

19. WEYNA E., BUCZKOWSKA-RADLIŃSKA J., GROCHOLEWICZ K. The safety of fluoride prophylaxis in the light of the knowledge of students, doctors and scientific evidence. Czas. Stomat., 58 (6), 397, 2005 [In Polish].

20. TYTZ-CHOJNOWSKA A., STRUŻYCKA I., SZANIAWSKA K. Assessment of knowledge of Malbork citizens on application of drinking water fluoridation. Nowa Stomatologia 4,152, 2010 [In Polish].

21. ADAMOWICZ-KLEPALSKA B., BORYSEWICZLEWICKA M., DOBRZAŃSKA A., JACKOWSKA T., KACZMAREK U., OLCZAK-KOWALCZYK D. Current knowledge of individual fluoride prevention of dental caries in children and young adults. J. Stoma. 66 (4), 428, 2013 [In Polish].

22. EUROPEAN ACADEMY OF PAEDIATRIC DENTISTRY. Guidelines on the use of fluoride in children: an EAPD policy document. Eur. Arch. Paediatr. Dent. 10 (3), 129, 2009.

23. WALNA B., KURZYCA I., BEDNORZ E., KOLENDOWICZ L. Fluoride pollution of atmospheric precipitation and its relationship with air circulation and weather patterns (Wielkopolski National Park, Poland). Environ. Monit. Assess. 185, 5497, 2013.

24. HEILMAN J.R., KIRITSY M.C., LEVY S.M., WEFEL J.S. Fluoride concentrations of infant foods. J Am. Dent Assoc. 128 (7), 857, 1997.

25. JĘDRA M., URBANEK-KARŁOWSKA B., GAWARSKA H., SAWILSKA-RAUTENSTRAUCH D. Fluoride content of soft drinks produced in Poland. Rocz. Państw. Zakł. Hig. 57 (3), 203, 2006.

26. OPYDO-SZYMACZEK J. Fluoride exposure from diet in infants and young children fed with the foodstuffs for particular nutritional uses. Dent. Med. Probl. 49 (2), 209, 2012.

27. OPYDO-SZYMACZEK J., OPYDO J. Fluoride content of beverages intended for infants and young children in Poland. Food Chem. Toxicol. 48 (10), 2702, 2010.

28. OPYDO-SZYMACZEK J., OPYDO J. Dietary fluoride intake from infant and toddler formulas in Poland. Food Chem. Toxicol. 49 (8), 1759, 2011.

29. OPYDO-SZYMACZEK J., OPYDO J. Fluoride content of selected infant foods containing poultry or fish marketed in Poland. Fluoride 44 (4), 232, 2011.

30. OPYDO-SZYMACZEK J., GERRETH K. Etiological factors related to dental fluorosis among children in Poznan, Poland - a preliminary report. Fluoride 45(4), 354, 2012.

31. EKAMBARAM M., ITTHAGARUN A., KING N.M. Ingestion of fluoride from dentifrices by young children and fluorosis of the teeth - a literature review. J. Clin. Pediatr. Dent. 36 (2), 111, 2011.

32. CZARNOWSKI W., WRZEŚNIOWSKA K., KRECHNIAK $K$. Fluoride in drinking water and human urine in Northern and Central Poland. Sci. Total. Environ. 191 (1-2), 177, 1996.

33. EUROPEAN COMMISSION. Council Directive 98/83/EC of 3 November 1998 on the quality of water intended for human consumption, O.J. L330/32., 5.12.1998.

34. POLISH MINISTER OF HEALTH. Regulation of the Minister of Health of 29 March 2007 on the quality of water intended for human consumption. Journal of Laws No. 61, item. 417, 2007.

35. POLISH MINISTER OF HEALTH. Regulation of the Minister of Heath dated 20 April 2010 amending the regulation on the quality of water intended for human consumption. Journal of Laws No. 72, item. 466, 2010.
36. CHIEF SANITARY INSPECTORATE. Sanitary state of the country in 2014. Warsaw: Chief Sanitary Inspectorate 2015 [In Polish].

37. CHIEF SANITARY INSPECTORATE. Sanitary state of the country in 2010. Warsaw: Chief Sanitary Inspectorate 2011 [In Polish].

38. CHIEF SANITARY INSPECTORATE. Sanitary state of the country in 2011. Warsaw: Chief Sanitary Inspectorate 2012 [In Polish].

39. CHIEF SANITARY INSPECTORATE. Sanitary state of the country in 2012. Warsaw: Chief Sanitary Inspectorate 2013 [In Polish].

40. CHIEF SANITARY INSPECTORATE. Sanitary state of the country in 2013. Warsaw: Chief Sanitary Inspectorate 2014 [In Polish].

41. WONS M. The quality of drinking water in the commune Gniew. J. of Research and Applications in Agr. Eng. 58 (4) 228, 2013.

42. GNIAZDOWSKA A. Quality of water in Opole District in 2011. Accessed 29 September 2015, Available at: http:// wsseopole.pis.gov.pl/plikijednostki/wsseopole/userfiles/ Jako\%C5\%9B\%C4\%87\%20wody.pdf [In Polish].

43. PODGÓRSKA B., GÓRNIAK J., SYNOWIEC P., JANOWSKA M., ORZECHOWSKI M., STELMACH M. Environment protection programme for Brzeg District in 2009-2012 with the perspective on 2013-2016. Accessed 29 September 2015, Available at: http://powiat.brzeski.opolski. sisco.info/zalaczniki/1516/APOS_Brzeg_powiat_8.pdf [In Polish].

44. SAUR NEPTUN GDAŃSK. Report of the city of Gdansk and Saur Neptun Gdansk on the quality of drinking water. August 2015. Accessed 29 September 2015, Available at: http://www.sng.com.pl/Portals/2/dok/jakosc_wody/ komunikat-jakosc_wody.pdf [In Polish].

45. WATER SUPPLIER OF TORUN. Public cretaceous wells. Accessed 29 September 2015, Available at: http://www. wodociagi.torun.com.pl/index.php?lang=PL\&m=page\&pg id=160[In Polish].

46. STATE DISTRICT SANITARY INSPECTOR IN PRUSZCZ GDAŃSKI. Territorial assessment of water quality for Gdańsk District in 2011. Accessed 29 September 2015, Available at: http://www.powiat-gdanski. $\mathrm{pl} /$ ?m=aktualnosci\&id_wiadomosci=572 [In Polish].

47. KOC J. WONS M., GLIŃSKA-LEWCZUK K. AND SZYMCZYK S. Content of Iron, Manganese and Fluorine in Groundwater and After its Purification to Potable Water. Pol. J. Environ. Stud. 15 (2a), 364, 2006.

48. U.S. DEPARTMENT OF HEALTH AND HUMAN SERVICES FEDERAL PANEL ON COMMUNITY WATER FLUORIDATION. U.S. Public Health Service Recommendation for Fluoride Concentration in Drinking Water for the Prevention of Dental Caries. Public Health Reports, 130, 1,July-August 2015.

49. WORLD HEALTH ORGANIZATION. Guidelines for drinking water quality, $3^{\text {rd }}$ ed., WHO: Geneva, Switzerland, 2004.

50. FOMON S.J., EKSTRAND J., ZIEGLER E.E. Fluoride intake and prevalence of dental fluorosis: trends in fluoride intake with special attention to infants. J. Public Health Dent. 60 (3), 131, 2000.

51. US INSTITUTE OF MEDICINE. STANDING COMMITTEE ON THE SCIENTIFIC EVALUATION OF DIETARY REFERENCE INTAKES. Dietary Reference Intakes for Calcium, Phosphorus, Magnesium, Vitamin $\mathrm{D}$, and Fluoride., National Academy Press, Washington 1997. 
52. THE COMMISSION OF THE EUROPEAN COMMUNITIES. Commission Directive 2006/ 141/EC of 22 December 2006 on infant formulae and follow-on formulae and amending Directive 1999/21/EC. O.J.E.U.L 401, 1, 2006.

53. KSIAZYK J.B., WEKER H. 2007. New feeding plan for infants in Poland, since 2007. Pediatr. Wspolcz. Gastroenterol. Hepatol. Zywienie Dziecka. 9, 9, 2007 [In Polish].

54. ADA Division of Communications. For the dental patient: infants, formula and fluoride. J. Am. Dent. Assoc. 138 (1), 132, 2007

55. EKSTRAND J. Fluoride intake in early infancy. J. Nutr. 119 (12 Suppl), 1856, 1989
56. BOTTENBERG P. Fluoride content of mineral waters on the Belgian market and a case report of fluorosis induced by mineral water use. Eur. J. Pediatr. 163 (10), 626, 2004.

57. POLISH MINISTER OF HEALTH. Regulation of the Minister of Health of 31 March 2011 on the natural mineral waters, spring waters and potable waters. Journal of Laws No. 85, item. 466, 2011.

58. BORYSEWICZ-LEWICKA M., CHŁAPOWSKA J., WAGNER L., TRYKOWSKI J. An evaluation of the fluoride content in some Polish mineral waters. Czas. Stomatol. 52 (1), 29, 1999 [In Polish].

59. OPYDO-SZYMACZEK J., OPYDO J. Fluoride content of bottled waters recommended for infants and children in Poland. Fluoride 42 (3), 233, 2009. 
